\title{
Sport commitment in adolescent soccer players
}

\section{Compromisso desportivo em atletas de futebol adolescentes}

\author{
Noelia Belando Pedreño ${ }^{1}$, Roberto Ferriz-Morel ${ }^{1}$, Shai Rivas ${ }^{1}$, Bartolomé Almagro ${ }^{3}$, Pedro \\ Sáenz-López ${ }^{3}$, Eduardo Cervelló ${ }^{1}$, Juan Antonio Moreno-Murcia ${ }^{*}$
}

\begin{abstract}
The aim of this study was to contribute to the postulates of the self-determination theory, the hierarchical model of intrinsic and extrinsic motivation by Vallerand, and social goals. A structural regression model was estimated to analyze the relations between social goals (responsibility and relationships), praise for autonomous behavior, satisfaction of the basic psychological needs and intrinsic motivation in commitment to sport. A sample of 264 young Spanish soccer players aged between 14 and $16(M=14.74, S D=.77)$ participated in the study. Structural Equation Modeling results showed that the social responsibility goal, the social relationship goal and praise for autonomous behavior predicted perceived competence. Furthermore, the relationship goal also predicted the need for relatedness. Satisfaction of the basic psychological needs for competence and relatedness predicted intrinsic motivation. Intrinsic motivation positively predicted future commitment to sport. These results highlighted the importance of social goals, praise for autonomous behavior and psychological mediators in encouraging greater commitment in young soccer players. Future research should focus on the coach's role in generating greater commitment to sport through the development of intervention methodologies based on social goals.
\end{abstract}

Keywords: social goals, relatedness, competence, sport commitment, intrinsic motivation, selfdetermination theory

O objetivo foi testar a capacidade preditiva das metas sociais (responsabilidade e socialização), a importância do comportamento autônomo, a satisfação das necessidades psicológicas básicas e motivação intrínseca no compromisso com o esporte. Contribuindo assim, com os fundamentos da teoria da autodeterminação, o modelo hierárquico da motivação intrínseca e extrínseca de Vallerand e as metas sociais. Participaram do estudo, 264 jovens futebolistas espanhóis de 14 a 16 anos $(M=14.74, S D=.77)$. Os resultados do modelo de equações estruturais mostrou que as metas de responsabilidade e socialização, e a importância do comportamento autônomo preveem a competência percebida. Além disso, a meta de socialização também previu a necessidade de vínculo social. Também, a satisfação das necessidades psicológicas básicas de competência percebida e vínculo social previram a motivação intrínseca. A motivação intrínseca predigo positivamente o compromisso esportivo. Estes resultados reafirmam a importância das metas sociais, a importância do comportamento autônomo e os mediadores psicológicos no sentido de incentivar maior compromisso esportivo em jovens jogadores de futebol. Futuras pesquisas que pretendem um maior compromisso esportivo, deveriam dar especial atenção na análise de como os técnicos realizam suas metodologias de intervenção, e como aplicam as estratégias motivacionais e as metas sociais. Palavras-chave: metas sociais, vínculo social, competência percebida, comportamento autônomo, motivação intrínseca, compromisso esportivo

\footnotetext{
Manuscript received at November $16^{\text {th }} 2013$; Accepted at May $14^{\text {th }} 2015$

${ }^{1}$ Miguel Hernández University of Elche, Spain

${ }^{2}$ University of Almería, Spain

${ }^{3}$ University of Huelva, Spain

* Corresponding author. Avda. de la Universidad, s/n 03130, Elche (Alicante), Spain E-mail: j.moreno@umh.es
} 


\section{INTRODUCTION}

Doing sufficient physical activity and sports during childhood and adolescence stimulates physical, cognitive and social development in young people (Duda \& Ntoumanis, 2003; van Beurden et al., 2003). If healthy sports habits are acquired during these stages of development, they could be maintained in adulthood, and consequently, dropping out of physical activity and sport could be avoided (Almagro, Sáenz-López, \& Moreno-Murcia, 2010; Caspersen, Pereira, \& Curran, 2000; Cervelló, Escartí, \& Guzmán, 2007). Different research papers (Sousa, Torregrosa, Viladrich, Villamarín, \& Cruz, 2007; Torregrosa \& Cruz, 2006) show that commitment to sport is a strong predictor of sports dropout, maintaining that if there is a greater commitment to sport then there is less possibility of dropping out. For this reason, and as one of the aims of this study, there is a clear need for knowledge about the level of future commitment to sport in a sample of young soccer players through the analysis of the effect of the relations between social goals (responsibility and relationships), praise for autonomous behavior, psychological mediators (perceived competence and relatedness) and intrinsic motivation.

\section{Praise for autonomous behavior}

In relation to the variables that can predict sport commitment, coaches play an important role. Authors like Conroy and Coastsworth (2007) assert that praise by the coach about an athlete's autonomous behavior, decisions and effort could influence the behaviors of satisfaction and commitment to sport. According to Moreno-Murcia, Gimeno, Pardo, and Dantas (2010), a training climate which considers the athletes, allowing them to participate in the decision making process and taking their opinion into account, seems to be a determining factor in their future commitment to sport. The coach could be responsible for generating a suitable environment (goals of responsibility towards practice and cooperation in the team) and motivation for encouraging athletes to continue doing physical activity and sports at a later age
(Ntoumanis, Vazou, \& Duda, 2007). In this line, in an international study with adolescent soccer players, Quested et al. (2013) support the applicability of the basic need theory (Deci \& Ryan, 2000; R. M. Ryan \& Deci, 2000) as a framework for understanding the determining factors for sports dropout among European youngsters.

\section{Self-Determination theory}

The Basic Need theory (BNT) is one of the mini theories which comprise the SelfDetermination Theory (SDT) (Deci \& Ryan, 1985), and indicates that there are three basic psychological needs (perceived autonomy, perceived competence and relatedness) that the social context should encompass if athletes are to achieve greater cognitive-social well-being. These psychological needs could mediate the influence of social factors and the athlete's level of motivation. For its part, the Integration Organism theory (IOT) (the mini-theory that explains the SDT), shows that motivation moves on a continuum of self-determination. The highest level of motivation is intrinsic motivation, which refers to carrying out an activity for the pleasure and satisfaction it gives; followed by extrinsic motivation, considered as the motivation that moves someone to act in order to obtain an external compensation; and finally amotivation, which is related to apathetic behaviors. In relation to this continuum, the levels of self-determination are modified according to the level of achievement of the three basic needs. In this sense, in different studies (e.g., García-Mas et al., 2010; Zahariadis, Tsorbatzoudis, \& Alexandris, 2006) intrinsic motivation has been shown as a fundamental variable for achieving an adequate commitment to sport. The association between intrinsic motivation and future commitment to sport seems logical, since intrinsic motivation implies a person's commitment to an activity for the enjoyment and pleasure that it produces, and therefore, the activity is a means to an end (Deci \& Ryan, 1985). In the area of sports, Smith, Ntoumanis, and Duda (2007) have demonstrated that coaches with a behavior of autonomy support 
in training sessions generate a greater perception of effort and a satisfaction of the basic psychological needs in athletes, thereby increasing intrinsic motivation.

As a complement to the postulates of the self-determination theory, the Hierarchical Model of Intrinsic and Extrinsic Motivation by Vallerand (1997) establishes that there are three levels of motivation: global (a person's general motivation), contextual (general orientation towards a specific context like sport) and situational (the motivation a person has during the development of a particular activity). This model complements the selfdetermination theory in that it considers that motivation experienced on one level can influence the rest of the levels. For example, if an adolescent has positive experiences during training (situational), he can develop positive attitudes towards a sport (contextual) and commit to an active life style (global).

\section{Social Goals}

Another social construct related to motivation is social goals (Anderman \& Anderman, 1999). In educational psychology, there has been an attempt to integrate social goals in the study of motivation, since this dimension influences people's behavior and performance (Guan, McBride, \& Xiang, 2006; Patrick, Hicks, \& Ryan, 1997). Several studies (Allen, 2003; Méndez-Giménez, CecchiniEstrada, Fernández-Río, \& González-Mesa, 2012; Stuntz \& Weiss, 2009) have identified the social aspects of motivation towards physical education and physical activity and sport as possible determining factors of the most self-determined motivation, which would bring positive consequences for adolescent athletes such as a greater adherence to physical activity and sport. This study has considered the responsibility goal that would reflect a desire to respect social rules and role expectations (Wentzel, 1991), and the social relationship goal that would refer to the desire to maintain good relations with teammates (Ryan, Hicks, \& Midgley, 1997). In this context, an athlete's goal might be to become a responsible person in training tasks, committed to the established rules, or being able to form friendships within the team. The consideration of social goals is especially important and appropriate for analyzing adherence to doing physical activity and sport during adolescence, since it is during this stage that relations with the peer group have greater importance, and there is an increase in social concerns like fulfilling their commitment to the team or to teammates, or feeling well related with others to confirm their competence in what they do (Urdan \& Maehr, 1995).

On the basis of the studies revised, it has been noted that commitment to sport is influenced by the social context that surrounds an athlete. Scanlan, Simons, Carpenter, Schmidt, and Keeler (1993) define commitment to sport as a psychological disposition which represents the desire and decision to continue to participate in sport. This is determined by the level of enjoyment, personal investments, involvement opportunities and social constraints, as well as social support (Scanlan, Russel, Beals, \& Scanlan, 2003). In this respect, in the context of physical education and in line with this study, Giménez, Estrada, Río, and Mesa (2012) reaffirm that the responsibility and relationship goals can determine satisfaction of the basic psychological needs, and that they should also be considered along with other social factors. Likewise, these authors found that the psychological mediators, relatedness and perceived competence, positively predicted intrinsic motivation, which in turn predicted intention to do physical activity and sport in the future. In line with these studies and others (Cecchini-Estrada, González-Mesa, MéndezGiménez, \& Fernández-Río, 2011; MorenoMurcia, Hernández-Paños, \& González-Cutre Coll, 2009), a structural regression model was designed where it was hypothesized that the social responsibility and relationship goals, along with praise for autonomous behavior would positively predict satisfaction of the basic psychological needs, which would predict intrinsic motivation, which in turn would predict future commitment to sport in adolescent athletes. 


\section{METHOD}

\section{Participants}

The study sample consisted of 264 young Spanish soccer players (all boys) aged between 14 and $16(M=14.74, S D=.77)$ from different clubs. All the athletes competed in the regional soccer league but in different categories corresponding to their age (according to the Real Federación Española de Fútbol (Spanish Royal Federation of Soccer): $20 \%$ of the sample belonged to the juvenile category (13-14 years old) and $80 \%$ of the sample belonged to the cadet category (15-16 years old). Athletes had been playing soccer institutionally since they were ten. The research was carried out on the 15 participating teams during the competition period. Non-probability and casual sampling is used (also known as convenience sampling).

\section{Measures}

Social Goal in Sport Scale.

The Spanish version (Moreno-Murcia, González-Cutre Coll, \& Sicilia-Camacho, 2007) of the Social Goal Scale-Physical Education (SGS-PE) by Guan, McBride, and Xiang (2006) was used. This scale consists of a total of 11 items grouped into two factors, the relationship goal (e.g., "I would like to get to know my friends who I train with very well ") and the responsibility goal (e.g., "I try to do what the coach asks me to do"). Answers were given on a 7-point Likert scale that range from 1 (strongly disagree) to 7 (strongly agree), preceded by the phrase "In my training sessions...". The original Cronbach alpha values for validation to the Spanish context were .75 for the relationship factor and .73 for the responsibility factor. The original scale also presented an adequate fit, as shown in the fit indices obtained in the confirmatory factor analysis: $\chi^{2}(43, \mathrm{~N}=406)=121.59, \mathrm{p}=.00$; $\chi^{2} /$ g.l. $=2.82 ; \mathrm{CFI}=.93 ; \mathrm{NFI}=.89 ; \mathrm{TLI}=.91$; RMSEA $=.06$; SRMR $=.04$. The internal consistency obtained was .75 for the responsibility dimension and.78 for relationship dimension.
Praise for autonomous behavior.

The factor, praise for autonomous behavior, from the Spanish version (Conde et al., 2010) from Conroy and Coatsworth's (2007) Autonomy-Supportive Coaching Questionnaire (ASCQ) was used. This factor comprises four items that measure how players evaluate praise for their autonomy. (e.g., "My coach assesses my choice of the things I do in training.") The questionnaire began with the phrase "In my training sessions...". The responses were limited to a Likert scale from 1 (strongly disagree) to 7 (strongly agree). The original Cronbach alpha value for validation to the Spanish context was .70. The internal consistency obtained was .77.

\section{Scale for Satisfaction of Psychological Needs.}

The Spanish version (Moreno-Murcia, Marzo, Martínez-Galindo, \& Conte-Marín, 2011) of the Psychological Need Satisfaction in Exercise Scale (PNSE; Wilson, Rogers, Rodgers, \& Wild, 2010). The questionnaire included 18 items (six items in each subscale) for measuring the competence factor (e.g., "I believe I can do the exercises that are a personal challenge"), the autonomy factor (e.g., "I believe I can choose the exercises in which I participate") and the relatedness factor (e.g., "I feel close to my team mates because they accept me as. I am.") The introductory statement was "In my training sessions ..." The answers were given on a Likert scale with a response range from 1 to 6 , where 1 corresponded to "False" and 6 to "true". The original Cronbach alpha values for validation to the Spanish context were .80 for perceived competence, .69 perceived autonomy and relatedness .73. The alpha values of the scale were .76 for the competence factor and .75 for the relatedness factor. The unreliability of the autonomy factor made it necessary to remove this psychological mediator for this study.

\section{Intrinsic motivation.}

The general intrinsic motivation factor from the Spanish version (Moreno-Murcia et al., 2011) of the Behavioral Regulation in Sport Questionnaire (BRSQ) by Lonsdale, Hodge, 
and Rose (2008) was used. The scale was preceded by the phrase "I take part in this sport ...." The factor consisted of four items, these were ("Because I enjoy it," "Because it's fun," "Because I find pleasure in it," and "Because I like it"). The answers were scored on a Likert scale ranging from 1 (absolutely false) to 7 (absolutely true). The original Cronbach alpha value for validation to the Spanish context was.78. An internal consistency value of .75 was obtained.

\section{Future commitment.}

The future commitment factor from the Personal Commitment Scale by Orlick (1990) and adapted to the Spanish context by Belando, Ferriz-Morell, and Moreno-Murcia (2012) to evaluate an individual player's commitment to being constant and dedicated to doing their sports. This factor had four items (e.g., "I really want to become an excellent competitor in my sport"), introduced by the phrase "In my training sessions...".The answers were limited to a Likert scale from 1 (Strongly Disagree) to 5 (Strongly Agree). An internal consistency value of .68 was obtained (this factor had the same Cronbach alpha in its original version). This value was considered acceptable because of the reduced number of items which comprise this factor (Hair, Anderson, Tatham, \& Black, 1998).

\section{Procedure}

Sports directors from the different clubs were contacted to inform them about the objective of the research and ask for their collaboration. Written authorization was asked for from parents of minors, and they were also informed about the purpose of the research. Before gathering data, the lead researcher interviewed the coaches for each team to explain the objective of the research and to arrange a time for completing the questionnaires during one of the weekly training sessions. The players participated voluntarily and the questionnaires were filled in anonymously before the training session. To ensure comprehension of the items, the researchers explained them one by one and explained how to complete the questionnaire. It took approximately 20 minutes for all of the questions. No difficulties were encountered in understanding the items.

\section{Data analysis}

Firstly, the descriptive statistics for all the target variables (averages and standard deviation) were calculated and internal consistency for each factor was analyzed by means of the Cronbach alpha coefficient and the bivariate correlations. Similarly, a structural regression model was calculated to analyze the hypothesized relations between the variables. The two-step approach proposed by Anderson and Gerbing (1988) was used: first, a measure model was calculated, which would give construct validity to the dimensions, based on the fourteen measures observed and the seven latent constructs which correlated freely; and secondly a structural regression model was formulated which analyzed the predictive relations between the social goals (responsibility and relationships), praise for autonomous behavior, psychological mediators (perceived competence and relatedness), intrinsic motivation and future commitment to sport. The statistical software SPSS 20.0 and AMOS 20.0 was used for the data analysis

$\begin{array}{ll}\text { Descriptive } & \text { RESULTS } \\ \text { analysis and ations } & \end{array}$ bivariate

The descriptive statistics in Table 1 revealed that the responsibility goal had a higher value than the relationship goal. While praise for autonomous behavior scored an average value of 5.07. Perceived competence was valued higher than relatedness. Intrinsic motivation had a mean value of 6.68 and future commitment showed a mean value of 4.23 . In the correlation analysis it was observed that all variables studied correlated positively and significantly with each other.

\section{Analysis of structural regression model}

In order to carry out the analysis of the measure model and to test the structural regression model (SEM), the number of latent 
factors per factor was reduced. This is especially recommended when the size of the sample is not particularly large compared with the number of the model variables (Marsh, Richard, Johnson, Roche, \& Tremayne, 1994; Vallerand, 2007). This reduction can be achieved by putting the items into pairs. So, half of the first items from each subscale were averaged to form the first block of items, and the second half were averaged to form the second block of items, and so on until the last one. Marsh, Richard, Johnson, Roche, and Tremayne (1994) proposed the use of item pairs because the results are more reliable, they tend to be distributed more normally, and the ratio of the variables measured in the model and the number of participants is halved.

Table 1

Descriptive statistic and bivariate correlations among variables

\begin{tabular}{|c|c|c|c|c|c|c|c|c|c|c|c|}
\hline Variables & $M$ & $S T$ & $\alpha$ & $\mathrm{R}$ & 1 & 2 & 3 & 4 & 5 & 6 & 7 \\
\hline Responsibility goal & 6.37 & .67 & .65 & $1-7$ & - & $.50 * *$ & $.47^{* *}$ & $.21 * *$ & $.15^{*}$ & $.33^{* *}$ & $.27 * *$ \\
\hline Relationship goal & 6.16 & .68 & .68 & $1-7$ & - & - & $.35^{* *}$ & $.22^{* *}$ & $.21^{* *}$ & $.41^{* *}$ & $.13^{*}$ \\
\hline Autonomous behavior & 5.07 & .20 & .69 & $1-7$ & - & - & - & $.21^{* *}$ & $.28^{* *}$ & $.28^{* *}$ & $.14^{*}$ \\
\hline Competence & 5.30 & .60 & .76 & $1-6$ & - & - & - & - & $.45^{* *}$ & $.35^{* *}$ & $.30 * *$ \\
\hline Relatedness & 5.10 & .67 & .75 & $1-6$ & - & - & - & - & - & $.37^{* *}$ & $.28^{* *}$ \\
\hline 6. Intrinsic motivation & 6.68 & .59 & .75 & $1-7$ & - & - & - & - & - & - & $.24^{* *}$ \\
\hline 7. Future sport commitment & 4.23 & .68 & .68 & $1-5$ & - & - & - & - & - & - & - \\
\hline
\end{tabular}

Note: ${ }^{*} p<.05 ;{ }^{* *} p<.01 ; M=$ Mean; $S T=$ Standard deviation; $\alpha=$ Cronbach's alpha; $\mathrm{R}=\mathrm{Range}$.

Since the Mardia coefficient was high (113.20), the maximum verisimilitude method was used along with the bootstrapping method, which allowed data to be assumed as robust in the presence of the lack of normality (Byrne, 2001). In the same way, a series of fit coefficients were considered to evaluate the measure models' goodness of fit with the empirical data. Therefore, based on the studies by different authors (Bentler, 1990; Bollen \& Long, 1993; McDonald \& Marsh, 1990), the fit indices or goodness of fit indices which were considered to evaluate the measure model were: $\chi^{2}, \chi^{2} /$ d.f., RMSEA (Root Mean Square Error of Approximation), RMSR (Root Mean Square Residual) and the incremental indices (CFI, IFI and TLI). These goodness of fit indices are considered acceptable when the $\chi^{2} /$ d.f. is lower than 5, the incremental indices (CFI, IFI and TLI) are higher than .90 and the error indices (RMSEA and RMSR) are lower than .08 (Hu \& Bentler, 1999). The indices obtained were adequate: $\chi^{2}(56, N=264)=88.68, p=$ $.00, \chi^{2} / \mathrm{df}=1.58, \mathrm{CFI}=.97, \mathrm{IFI}=.95, \mathrm{TLI}=$ .97 , SRMR $=.04$, RMSEA $=.05$. In addition, the discriminating validity of the model was examined, keeping in mind that the correlation between the latent variables attenuated by the measurement error $(+/$ - 2 times the measurement error) was lower than 1.0. The different results indicate that the measurement model was adequate.

The second step of the method consisted in verifying the measure model and the structural regression model simultaneously, which permits focusing on the conceptual interactions between the latent factors: social goals (responsibility and relationships) praise for autonomous behavior, psychological mediators (perceived competence and relatedness), intrinsic motivation and future commitment to sport. Thus, the data obtained was: $\chi^{2}$ (67, $N=264)=128.93, p=.00, \chi^{2} / \mathrm{d} . \mathrm{f}=1.92$, CFI $=.94$, IFI $=.94$, TLI $=.92$, SRMR $=.06$, RMSEA $=.06$. This data fit the established parameters, so the proposed model is considered adequate.

The results from the structural equations model (Figure 1) established that the responsibility goal, praise for autonomous behavior and the relationship goal, positively predicted perceived competence; the relationship goal also predicted the need for relatedness. As far as perceived competence and relatedness were concerned, they positively predicted intrinsic motivation. In turn, intrinsic motivation positively predicted future commitment to sport. The following variances were obtained: $32 \%$ for intrinsic motivation and $13 \%$ for commitment to sports. 


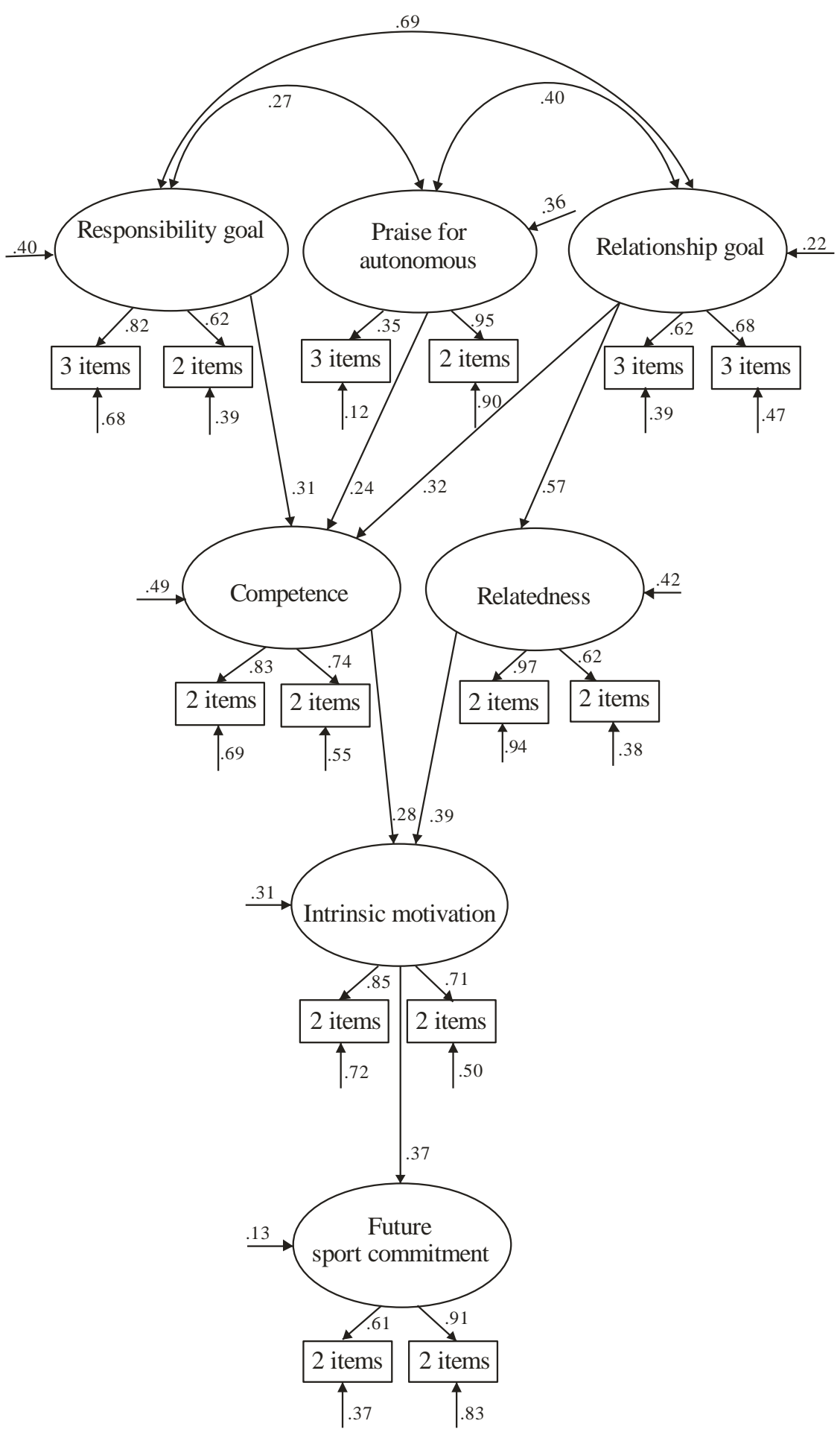

Figure 1. Structural equation model (SEM) that demonstrate the relationships between social goals of responsibility and relationship, praise for autonomous behavior, competence, relatedness, intrinsic motivation, and the future sport commitment. All the parameters are standardized and are statistically significant.

\section{DISCUSSION}

The purpose behind this study was to complete the sequence of motivational processes proposed by the self-determination theory and the model by Vallerand (1997) in order to explain the level of sports commitment in adolescents. To do so, a predictive model was estimated where the relations between the social goals (responsibility and relationship), praise for autonomous behavior, psychological mediators (perceived competence and relatedness), intrinsic motivation and future 
commitment to sport were analyzed. In the analysis of the structural regression model, the hypothesis presented was partially confirmed. Social responsibility and social relationship goals, as well as praise for autonomous behavior positively predicted satisfaction of the need for perceived competence On the other hand, only the social relationship goal predicted the need for relatedness. These results are consistent with some studies developed in physical education (MorenoMurcia et al., 2007; Moreno-Murcia, Vera, \& Cervelló, 2008), which show that the responsibility goal positively predicted perceived competence. In the same way, in other research (Boyd, Weinmann, \& Yin, 2002; Hassandra, Goudas, \& Chroni, 2003; Li, Lee, \& Solmon, 2005) the acceptation of responsibility in learning is indicated as the source of improvement in competence, and the authors point out that the students who are perceived as more competent are the most motivated. Adolescents that are responsible for role expectations are likely to be committed to following the team rules, to value relations with their teammates, and in practice feel more competent (Méndez-Giménez et al., 2012). In accordance with the postulates of the selfdetermination theory (Deci \& Ryan, 1980), it is possible to observe the effect of social factors (represented by the coach's praise for the athlete's autonomous behavior) on the satisfaction of the basic psychological needs.

Looking further into the model presented and the postulates of the hierarchical model by Vallerand (1997, 2007), ensuring satisfaction of the basic needs of perceived competence and relatedness positively predicted intrinsic motivation. This in turn, predicted future commitment to sport. In this sense, intrinsic motivation has been shown to be a fundamental variable for achieving an adequate commitment to sport in different studies (García-Mas et al., 2010; Jõesaar, Hein, \& Hagger, 2011; Zahariadis et al., 2006). This idea is supported by other studies (Boixadós, Cruz, Torregrosa, \& Valiente, 2004; GarcíaCalvo, Marcos, Clemente, \& Miguel, 2008; Sousa, Cruz, Torregrosa, Vilches, \& Viladrich,
2007), which indicate that a high level of sport commitment shown by adolescents is a consequence of the effect of the learning context that the coach develops regarding perceived competence and relatedness, which could generate a greater intrinsic motivation in them.

The results obtained could have pedagogical and procedural implications for training sessions. Coaches should give priority to effort, personal achievement, provide positive feedback, and set short term goals adapted to the athlete's level (Moreno-Murcia \& MartinezGalindo, 2011). What is more, the goal all sports programs could pursue could focus on the development of regular physical activity patterns in order to promote participation in adulthood and, therefore, improve the health of the population (Ntoumanis, 2002).

However, some limitations should be considered since only the responsibility and relationship goals were taken into account, and other goals such as the social status goal or social recognition goal were not. Furthermore, although a trainer's praise for an athlete's autonomous behavior is a different construct to social goals, we consider that it could act as a social trigger on the same level as social goals, because of its influence on guaranteeing the satisfaction of the basic psychological needs (explained in the introduction). Besides this, the lack of reliability of the autonomy dimension made it necessary to eliminate this psychological mediator as in the case of other studies in the Spanish context (e.g., MéndezGiménez et al., 2012). Furthermore, the internal consistency for this psychological mediator was lower than .60 and was not explained by either social goals or by praise for autonomous behavior. Adolescents are likely to have a certain difficulty in understanding and assimilating the need of perceived autonomy as the ability to make decisions about the activities the coach proposes, showing personal initiative in training sessions and matches, and being responsible for their role in the team; but not as the ability to decide and act as they please. Likewise, it should be noted that this study uses a correlational methodology, 
making it necessary to carry out experimental studies to analyze the cause-effect relations with respect to the variables studied, so that the common method bias is controlled (Podsakoff, MacKenzie, Lee, \& Podsakoff, 2003). Furthermore, the data cannot be extrapolated beyond the ranges observed in the study sample. In which case, the model proposed is the one which showed the best fit, but due to the problem of equivalent models which the structural equation technique presents (Hershberger, 2006), it is assumed that the model presented would not be the only one possible. In this sense, experimental research could make an in-depth analysis of the psycho-social factors which would influence, facilitate and reinforce young people to do physical activity, trying to strengthen the feeling of persistence in doing sport throughout their lives. The estimation of theoretical models founded on constructs such as motivational climate (coach's facilitating or controlling style), social goals, peer influence and family environment could be of interest in order to look deeper into the appearance of more adaptive behaviors towards physical activity and sport. Likewise, these theoretical models could be contrasted in longitudinal studies, which guarantee a follow-up of the evolution of the rate of exercise in vital life stages

\section{CONCLUSION}

According to the above, and supported by the results observed, the main contribution of this study is to test the predictive potential of the responsibility goal, the relationship goal, and praise for autonomous behavior on the satisfaction of the needs of competence and social relations, intrinsic motivation and commitment to sport. This study reaffirms the idea of the influence of social factors and athletes' goals, so that they feel their perceived competence and relatedness are satisfied. Also, these psychological needs could mediate the relation between social factors and higher levels of intrinsic motivation related to a higher continuity in physical activity and sport (Tessier et al., 2013).

\section{Acknowledgments:}

Nothing to declare.

\section{Conflicts of Interest:}

Nothing to declare.

\section{Funding:}

The author(s) disclosed that they received the following support for their research and/or authorship of this article: This research was supported by a Master's Thesis Research the Ministry of Education of the Valencian Community (Spain), called ProgramaVali+d 2011/2014.

\section{REFERENCES}

Allen, J. B. (2003). Social motivation in youth sport. Journal of Sport and Exercise Psychology, 25, 551-567.

Almagro, B. J., Sáenz-López, P., \& Moreno-Murcia, J. A. (2010). Prediction of Sport Adherence Through the Influence of AutonomySupportive Coaching Among Spanish Adolescent Athletes. Journal of Sports Science \& Medicine, 9(1), 8-14.

Anderman, L. H., \& Anderman, E. M. (1999). Social Predictors of Changes in Students' Achievement Goal Orientations. Contemporary Educational Psychology, 24(1), 21-37. http://doi.org/10.1006/ceps.1998.0978

Anderson, J. C., \& Gerbing, D. W. (1988). Structural equation modeling in practice: A review and recommended two-step approach. Psychological Bulletin, 103(3), 411-423. http://doi.org/10.1037/0033-2909.103.3.411

Belando, N., Ferriz-Morell, R., \& Moreno-Murcia, J. A. (2012). Validación De La Escala De Grado De Compromiso Deportivo En El Contexto Español. Motricidad. European Journal of Human Movement, 28, 111-124.

Bentler, P. M. (1990). Comparative fit indexes in structural models. Psychological Bulletin, $107(2)$,

238-246. http://doi.org/10.1037/0033-2909.107.2.238

Boixadós, M., Cruz, J., Torregrosa, M., \& Valiente, L. (2004). Relationships among motivational climate, satisfaction, perceived ability, and fair play attitudes in young soccer players. Journal of Applied Sport Psychology, 16(4), 301-317. http://doi.org/10.1080/10413200490517977

Bollen, K. A., \& Long, J. S. (1993). Testing Structural Equation Models. Newbury Park, CA: SAGE Publications. 
Boyd, M. P., Weinmann, C., \& Yin, Z. N. (2002). The relationship of physical self-perceptions and goal orientations to intrinsic motivation for exercise. Journal of Sport Behavior, 25(1), 118.

Byrne, B. M. (2001). Structural Equation Modeling with AMOS: Basic Concepts, Applications, and Programming. London: Taylor \& Francis.

Caspersen, C. J., Pereira, M. A., \& Curran, K. M. (2000). Changes in physical activity patterns in the United States, by sex and cross-sectional age. Medicine and Science in Sports and Exercise, 32(9), 1601-1609. http://doi.org/10.1097/00005768200009000-00013

Cecchini-Estrada, J. A., González-Mesa, C., MéndezGiménez, A., \& Fernández-Río, J. (2011). Achievement goals, social goals, and motivational regulations in physical education settings. Psicothema, 23(1), 51-57.

Cervelló, E. M., Escartí, A., \& Guzmán, J. F. (2007). Youth sport dropout from the achievement goal theory. Psicothema, 19(1), 65-71.

Conde, C., Sáenz-López, P., Carmona, J., GonzálezCutre, D., Martínez, C., \& Moreno-Murcia, J. A. (2010). Validation of the AutonomySupportive Coaching Questionnaire (ASCQ) in young Spanish athletes. Estudios de Psicología, 31(2), 145-157. http://doi.org/10.1174/021093910804952250

Conroy, D. E., \& Coatsworth, D. J. (2007). Assessing autonomy-supportive coaching strategies in youth sport. Psychology of Sport and Exercise, $8(5)$, 671-684. http://doi.org/10.1016/j.psychsport.2006.12.0 01

Deci, E. L., \& Ryan, R. M. (1980). The empirical exploration of intrinsic motivational processes. Em L. Berkowitz (Ed.), Advances in experimental social psychology (Vol. 13, pp. 39-80). New York: Academic Press.

Deci, E. L., \& Ryan, R. M. (1985). Intrinsic motivation and self-determination in human behavior. New York: Plenum.

Deci, E. L., \& Ryan, R. M. (2000). The "What" and "Why" of Goal Pursuits: Human Needs and the Self-Determination of Behavior. Psychological Inquiry, 11(4), 227-268. http://doi.org/10.1207/S15327965PLI1104_0 1

Duda, J. L., \& Ntoumanis, N. (2003). Correlates of achievement goal orientations in physical education. International Journal of Educational Research, 39(4-5), 415-436. http://doi.org/10.1016/j.ijer.2004.06.007

García-Calvo, T., Marcos, F. M. L., Clemente, E. M., \& Miguel, P. A. S. (2008). El compromiso deportivo y su relación con factores disposicionales y situacionales contextuales de la motivación. Revista Internacional de Ciencias del Deporte, 4(12), 45-58.
García-Mas, A., Palou, P., Gili, M., Ponseti, X., Borras, P. A., Vidal, J., ... Sousa, C. (2010). Commitment, enjoyment and motivation in young soccer competitive players. The Spanish Journal of Psychology, 13(2), 609-616.

Guan, J., McBride, R. E., \& Xiang, P. (2006). Reliability and validity evidence for the Social Goal Scale-Physical Education (SGS-PE) in high school setting. Journal of Teaching in Physical Education, 25(2), 226-238.

Hair, J. F., Anderson, R. E., Tatham, R. L., \& Black, W. C. (1998). Multivariate Data Analysis. Upper Saddle River, NJ: Prentice Hall.

Hassandra, M., Goudas, M., \& Chroni, S. (2003). Examining factors associated with intrinsic motivation in physical education: a qualitative approach. Psychology of Sport and Exercise, 4(3), 211-223. http://doi.org/10.1016/S14690292(02)00006-7

Hershberger, S. L. (2006). The problem of equivalent structural models. Em G. R. Hancock \& R. O. Mueller (Eds.), Structural equation modeling: a second course (pp. 13-42). Greenwich, CT: IAP-Information Age Publishing.

Hu, L., \& Bentler, P. M. (1999). Cutoff criteria for fit indexes in covariance structure analysis: Conventional criteria versus new alternatives. Structural Equation Modeling: A Multidisciplinary Journal, 6(1), 1-55. http://doi.org/10.1080/10705519909540118

Jõesaar, H., Hein, V., \& Hagger, M. S. (2011). Peer influence on young athletes' need satisfaction, intrinsic motivation and persistence in sport: A 12-month prospective study. Psychology of Sport and Exercise, 12(5), 500-508. http://doi.org/10.1016/j.psychsport.2011.04.0 05

Li, W., Lee, A. M., \& Solmon, M. A. (2005). Relationships among dispositional ability conceptions, intrinsic motivation, perceived competence, experience, persistence, and performance. Journal of Teaching in Physical Education, 24(1), 51-65.

Lonsdale, C., Hodge, K., \& Rose, E. A. (2008). The behavioral regulation in sport questionnaire (BRSQ): instrument development and initial validity evidence. Journal of Sport \& Exercise Psychology, 30(3), 323-355.

Marsh, H. W., Richard, G. E., Johnson, S., Roche, L., \& Tremayne, P. (1994). Physical selfdescription questionnaire: psychometric properties and a nultitrait-multimethod analysis of relations to existing instruments. Journal of Sport and Exercise Psychology, 16(3), 270-305.

McDonald, R. P., \& Marsh, H. W. (1990). Choosing a multivariate model: Noncentrality and goodness of fit. Psychological Bulletin, 107(2), 247-255. http://doi.org/10.1037/00332909.107.2.247

Méndez-Giménez, A., Cecchini-Estrada, J. A., Fernández-Río, J., \& González-Mesa, C. 
(2012). Self-determination and social goals: a structural model for understanding the practical intention, effort and boredom in physical education. Aula abierta, 4O(1), 51-62.

Moreno-Murcia, J. A., Gimeno, E. C., Pardo, P. J. M., \& Dantas, E. E. M. (2010). Importance of praise for autonomous behavior for the enjoyment of aquatic exercise programs. Cuadernos de Psicología del Deporte, 10(1), 57-70.

Moreno-Murcia, J. A., González-Cutre Coll, D., \& Sicilia-Camacho, A. (2007). Social goals in physical Education class. Análisis $y$ modificación de conducta, 33(149), 351-368.

Moreno-Murcia, J. A., Hernández-Paños, A., \& González-Cutre Coll, D. (2009). Completing the self-determination theory with social goals: a study about enjoyment of physical education. Revista Mexicana de Psicología, 26(2), 213222.

Moreno-Murcia, J. A., \& Martinez-Galindo, C. (2011). Guía para una práctica deportiva igualatoria. Barcelona: INDE.

Moreno-Murcia, J. A., Marzo, J. C., MartínezGalindo, C., \& Conte-Marín, L. (2011). Validation of Psychological Need Satisfaction in Exercise Scale and the Behavioural Regulation in Sport Questionnaire to the Spanish context. Revista Internacional de Ciencias del Deporte, 7(26), 355-369. http://doi.org/10.5232/ricyde2011.02602

Moreno-Murcia, J. A., Vera, J. A., \& Cervelló, E. M. (2008). Efectos de la cesión de responsabilidad de la evaluación en la motivación y la competencia percibida en al aula de educación física. Revista de Educación, 348, 423-440.

Ntoumanis, N. (2002). Motivational clusters in a sample of British physical education classes. Psychology of Sport and Exercise, 3(3), 177194. 0292(01)00020-6

http://doi.org/10.1016/S1469-

Ntoumanis, N., Vazou, S., \& Duda, J. L. (2007). Peer-created motivational climate. Em S. Jowett \& D. Lavallee (Eds.), Social Psychology in Sport (pp. 145-156). Champagn, IL: Human Kinetics.

Orlick, T. (1990). In Pursuit of Excellence: How to Win in Sport and Life Through Mental Training. Champagn, IL: Leisure Press.

Patrick, H., Hicks, L., \& Ryan, A. M. (1997). Relations of perceived social efficacy and social goal pursuit to self-efficacy for academic work. The Journal of Early Adolescence, 17(2), 109128.

http://doi.org/10.1177/027243169701700200 1

Podsakoff, P. M., MacKenzie, S. B., Lee, J.-Y., \& Podsakoff, N. P. (2003). Common method biases in behavioral research: a critical review of the literature and recommended remedies. The Journal of Applied Psychology, 88(5), 879-
903.

9010.88.5.879

Quested, E., Ntoumanis, N., Viladrich, C., Haug, E., Ommundsen, Y., Hoye, A. V., ... Duda, J. L. (2013). Intentions to drop-out of youth soccer: A test of the basic needs theory among European youth from five countries. International Journal of Sport and Exercise Psychology, 11(4), 395-407. http://doi.org/10.1080/1612197X.2013.8304 31

Ryan, A. M., Hicks, L., \& Midgley, C. (1997). Social goals, academic goals, and avoiding seeking help in the classroom. The Journal of Early Adolescence, 17(2), 152-171. http://doi.org/10.1177/027243169701700200 3

Ryan, R. M., \& Deci, E. L. (2000). Self-determination theory and the facilitation of intrinsic motivation, social development, and wellbeing. The American Psychologist, 55(1), 6878. 066X.55.1.68

Scanlan, T. K., Russel, D. G., Beals, K. P., \& Scanlan, L. A. (2003). Sport Psychology project on elite athlete commitment (PEAK): II. A direct test and expansion of the sport commitment model with elite amateur sportsmen. Journal of Sport and Exercise Psychology, 25(3), 377-401.

Scanlan, T. K., Simons, J. P., Carpenter, P. J., Schmidt, G. W., \& Keeler, B. (1993). The sport commitment model: measurement development for the youth-sport domain. Journal of Sport and Exercise Psychology, 15(1), 16-38.

Smith, A., Ntoumanis, N., \& Duda, J. (2007). Goal striving, goal attainment, and well-being: adapting and testing the self-concordance model in sport. Journal of Sport \& Exercise Psychology, 29(6), 763-782.

Sousa, C., Cruz, J., Torregrosa, M., Vilches, D., \& Viladrich, C. (2007). Evaluación conductual y programa de asesoramiento personalizado a entrenadores (PAPE) de deportistas jóvenes. Revista de Psicologia del Deporte, 15(2), 263278.

Sousa, C., Torregrosa, M., Viladrich, C., Villamarín, F., \& Cruz, J. (2007). The commitment of young soccer players. Psicothema, 19(2), 256262.

Stuntz, C. P., \& Weiss, M. R. (2009). Achievement goal orientations and motivational outcomes in youth sport: The role of social orientations. Psychology of Sport and Exercise, 10(2), 255262.

http://doi.org/10.1016/j.psychsport.2008.09.0 01

Tessier, D., Smith, N., Tzioumakis, Y., Quested, E., Sarrazin, P., Papaioannou, A., ... Duda, J. L. (2013). Comparing the objective motivational climate created by grassroots soccer coaches in England, Greece and France. International 
14 | NB Pedreño, R Ferriz-Morel, S Rivas, B Almagro, P Sáenz-López, E Cervelló, JA Moreno-Murcia

Journal of Sport and Exercise Psychology, 11(4), 365-383. http://doi.org/10.1080/1612197X.2013.8312 59

Torregrosa, M., \& Cruz, J. (2006). El deporte infantil como base de la carrera deportiva de adultos activos y deportistas de élite. Em E. J. Garcés de los Fayos, A. Olmedilla, \& P. Jara (Eds.), Physichology and Sport (pp. 585-602). Murcia: Diego Marín.

Urdan, T. C., \& Maehr, M. L. (1995). Beyond a twogoal theory of motivation and achievement: a case for social goals. Review of Educational Research, 65(3), 213-243. http://doi.org/10.3102/00346543065003213

Vallerand, R. J. (1997). Toward A Hierarchical Model of Intrinsic and Extrinsic Motivation. Em M. P. Zanna (Ed.), Advances in Experimental Social Psychology (Vol. 29, pp. 271-360). New York: Academic Press. Obtido de

http://www.sciencedirect.com/science/article /pii/S0065260108600192

Vallerand, R. J. (2007). Intrinsic and extrinsic motivation in sport and physical activity. A review a look at the future. Em G. Tenenbaum \& R. C. Eklund (Eds.), Handbook of Sport
Psychology (3rd ed., pp. 59-83). Hoboken, New Jersey: John Wiley \& Sons, Inc. Obtido de http://onlinelibrary.wiley.com/doi/10.1002/9 781118270011.ch3/summary

van Beurden, E., Barnett, L. M., Zask, A., Dietrich, U. C., Brooks, L. O., \& Beard, J. (2003). Can we skill and activate children through primary school physical education lessons? «Move it Groove it»--a collaborative health promotion intervention. Preventive Medicine, 36(4), 493501. 7435(02)00044-0

Wentzel, K. R. (1991). Social Competence at School: Relation between Social Responsibility and Academic Achievement. Review of Educational Research, 61(1), 1-24. http://doi.org/10.2307/1170665

Wilson, P. M., Rogers, W. T., Rodgers, W. M., \& Wild, T. C. (2010). The psychological need satisfaction in exercise scale. Journal of Sport and Exercise Psychology, 28(3), 231-251.

Zahariadis, P., Tsorbatzoudis, H., \& Alexandris, K. (2006). Self-determination in sport commitment. Perceptual and Motor Skills, 102(2), 405-420. http://doi.org/10.2466/pms.102.2.405-420 